\title{
Aspects of nitrogen and mineral nutrition in Icelandic reindeer, Rangifer tarandus
}

\author{
Leah A. Chase, ${ }^{*} \dagger$ Eugene H. Studier* and Skarphedinn Thorisson $\ddagger$
}

*Department of Biology, University of Michigan-Flint, Flint, MI 48502-2186, U.S.A.; and

+ The Wildlife Management Institute, Hlemmi 3, P.O. Box 5032, 125 Reykjavik, Iceland

Nitrogen and mineral ( $\mathrm{Fe}, \mathrm{Mg}, \mathrm{Na}, \mathrm{K}$, and $\mathrm{Ca}$ ) compositions of foodstuffs consumed by and dung produced by male, pregnant and lactating female adult Icelandic reindeer and calves were determined during May of 1992. Iron levels in foodstuffs are consistently above the reported toxicity level for similar-sized sheep $(0.5 \mathrm{ppt})$ and may lead to iron toxicity when consumed by reindeer during periods of high lean body mass catabolism. Male and female reindeer meet nutrient requirements for all measured elements and nitrogen with the possible exception of calcium for males during antler growth.

Key words: Nitrogen nutrition; Mineral nutrition; Rangifer tarandus.

Comp. Biochem. Physiol. 109A, 63-73, 1994.

\section{Introduction}

A variety of studies has been done pertaining to caloric, mineral and nitrogen nutrition of feral and domestic reindeer in many areas including British Columbia, Finland, Svalbard and Norway (White et al., 1984; McEwan and Whitehead, 1970; Staaland et al., 1983). However, such research has not been done in Iceland. Iceland is of relatively recent volcanic origin, unlike most other areas in which reindeer have been studied. As a result, soil characteristics are more primitive and different. Since mineral composition of soil directly influences plant composition (National Research Council, 1985), Icelandic reindeer may consume similar plants with varied mineral

Correspondence to: E. H. Studier, Department of Biology, University of Michigan-Flint, Flint, MI 48502-2186, U.S.A. Tel. 810-762-3360; Fax 810-762-3687.

†Present address: Department of Pharmacological and Physiological Sciences, University of Chicago, 947 East 58th St., Chicago, IL 60637, U.S.A.

Received 16 September 1993; accepted 21 February 1994. composition or different plant species altogether.

Dung from pregnant and lactating female and male Icelandic reindeer, along with plant species known to be consumed were analysed. During May, females and males are in separate herds in eastern Iceland and Vesturoraefi, which are reindeer summering and calving grounds, respectively (Thorisson, 1984). Vesturoraefi is closer to more (active and inactive) volcanos, Askja in particular, than the eastern shore of Iceland; therefore, reproductively active female reindeer may be more influenced by volcanic ash than males.

Differences in migration and reproductive cycles of female and male reindeer may also contribute to differences in nutritional needs and available foodstuffs throughout the year. This study begins to analyse those differences in females in Vesturoraefi and males in eastern fjords during May 1992. Analysis of energy, mineral and nitrogen composition of Icelandic reindeer fecal samples and foodstuffs eaten is helpful in 


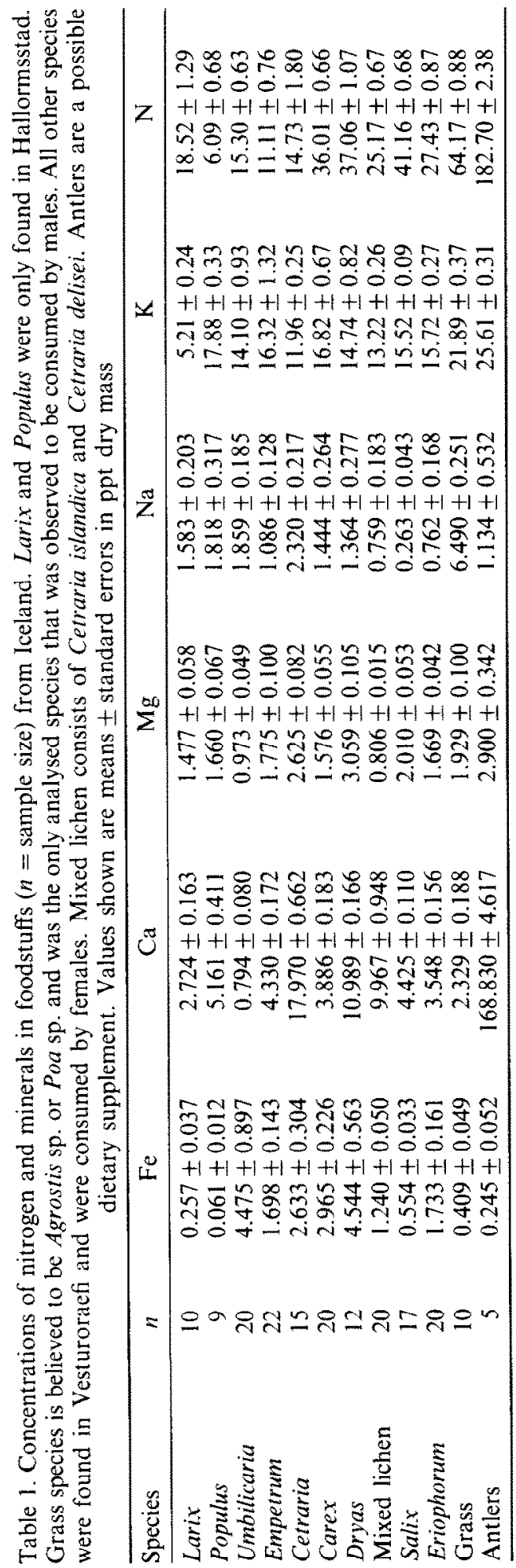

determining possible nutritional stresses or inadequacies of reindeer.

\section{Materials and Methods}

Plants known to be consumed by Icelandic reindeer and dung samples from males, lactating and pregnant females, and calves were collected in various regions of eastern Iceland between 7 and 22 May 1992. Samples were routinely handled with woolen gloves to avoid contamination and were placed into individual plastic zip-lock bags. Each sample's wet mass (to $0.01 \mathrm{~g}$, American Scientific battery powered scale) was obtained shortly after collection. Samples were frozen and subsequently unfrozen and then dried at approximately $60^{\circ} \mathrm{C}$ to about half the original wet mass to prevent microbial contamination during storage and transport.

Samples of $0.5-3.0 \mathrm{~g}$ fresh mass of each plant species were collected in regions where dung was collected. Only those portions of plants (new growth, entire plant and individual leaves) observed to be eaten were collected. Bark of Larix sukaczewi and Populus trichocarpa was collected in Hallormsstadur near Skograekt Rikisins Forestry Station where reindeer were known to have damaged young saplings. Portions of bark were removed with a sharp stainless steel blade from the base of trees. Umbilicaria sp. (black lichen) and Empetrum nitrum (crowberry) samples were collected south of Hallormsstadur. A grass, identified later as Agrostis sp. or $P o a$ sp., was collected in a field surrounded by a wire fence at Berufjordur. Cetraria nivalis, Dryas octopetala, Carex bigelowit, Cetraria islandica, Cetraria delisei, Salix callicarpaea and Eriophorum angustifolium were collected in Vesturoraefi.

Reindeer fresh dung samples (5.0-25.0 g wet mass) were collected from individuals identified by gender, age and reproductive condition. Dung samples of males were obtained in four areas along the eastern fjords: Berufjordur, Hamarsfjordur, Flatey in Myrar, and on the east side of Lake Thveit. Dung samples from pregnant females were collected in Vesturoraefi, except for one sample at Kidufell, south of Hallormsstadur. Dung samples were collected from lactating females in Skriddalur 
and Vesturoraefi and from calves in Vesturoraefi. Males were identified by short, new antler growth. Lactating and pregnant females had complete antlers, but lactating females were differentiated by the presence of their calf. Ages of calves were approximated, based on size and locomotion capabilities.

The partially dried food and dung samples were returned to the University of Michigan-Flint for analysis. Samples were placed in individual aluminium dishes and dried to a constant mass at $60^{\circ} \mathrm{C}$. Fat composition was also analysed (not reported here); therefore, $60^{\circ} \mathrm{C}$ was the maximum temperature samples were dried at to prevent loss of volatile fatty acids. Each dried sample was individually ground to a fine powder in a Braun coffec grinder, placed into polystyrene tubes, and sealed with plastic caps. Dried antler pieces were ground by a CRC Micromill.

Replicate $100 \mathrm{mg}$ (weighed to $0.1 \mathrm{mg}$ ) dry mass plant and fecal subsamples were digested as described by Studier and Sevick (1992). Samples were analysed with a Varian Spectra AA-20 atomic absorption instrument (Varian Techtron Ptg. Ltd., Springvale, Australia) for $\mathrm{Na}^{+}$and $\mathrm{K}^{+}$by atomic emission and $\mathrm{Ca}^{2+}, \mathrm{Mg}^{2+}$ and total iron $\left(\mathrm{Fe}^{2+}\right.$ and $\left.\mathrm{Fe}^{3+}\right)$ by atomic absorption. Nitrogen concentration of digested samples was determined by Nesslerization (Treybig and Haney, 1983).

Ash content of each sample was determined for replicate $500 \mathrm{mg}$ subsamples and put into preweighed crucibles which were placed in an ashing oven for $6 \mathrm{hr}$ at $500^{\circ} \mathrm{C}$. The final mass of the crucibles was obtained to determine ash content. Additional analyses of collected samples for water, fat, non-fat organic and caloric contents are reported elsewhere (Chase, 1993).

Data were analysed by a one way ANOVA followed by a priori orthogonal contrast $t$-tests. using SYSTAT (Wilkinson, 1989). Results were determined significant if $P<0.05$.

\section{Results}

Mineral and nitrogen concentrations of reindeer foodstuffs are listed by specics in Table 1. Differences were expected in mineral and nitrogen composition of foodstuffs available to reindeer; therefore, a priori orthogonal contrasts were performed. Differences were highly significant in all element compositions of plant species (Table 2). Barks of Larix sukaczewi and Populus trichocarpa were similar in element composition with the exception of calcium, potassium, and nitrogen. Collectively, Larix and Populus are significantly different than other potential foodstuffs available in Hallormsstadur with respect to iron, calcium, magnesium and potassium composition. Significant differences were also found between the grass eaten by male reindeer and all other nonbark species for nitrogen and all minerals, except magnesium. Finally, lichen species were different from all other nonbark, nonlichen species in all element compositions except sodium. Differences in ash content were also noted.

Mineral and nitrogen composition of drug samples are listed in Table 3. Samples

Table 2. One-way ANOVA results (F) on nutrient element levels in 11 potential caribou foodstuffs $(\mathrm{d} . \mathrm{f} .=10$, 164 and $P<0.001)$. A priori orthogonal contrast results are listed as (d.f. $=1,164)$ : $F 1$ and $P 1=H o$ : Larix $=$ Populus; F2 and P2 $=\mathrm{Ho}$ : barks = other potential foods available at that site; F3 and P3= Ho: grass $=$ non-bark potential foods; $F 4$ and $\mathbf{P} 4=$ Ho: lichens $=$ all other non-bark foods. One-way ANOVA results of ash (gash) content per gram dry mass $(\mathrm{gdm})$ and per gram ash-free dry mass (gafd) $(\mathrm{d} . \mathrm{f} .=9,96)$ and the respective a priori orthogonal contrast results. Non-significant values $(P>0.05)$ are listed as ns

\begin{tabular}{lrllrcrrrr}
\hline Element & \multicolumn{1}{c}{$\mathrm{F}$} & $\mathrm{F} 1$ & $\mathrm{P1}$ & $\mathrm{F} 2$ & $\mathrm{P} 2$ & $\mathrm{F3}$ & $\mathrm{P} 3$ & $\mathrm{~F} 4$ & $\mathrm{P4}$ \\
\hline $\mathrm{Fe}$ & 13.88 & 0.07 & $\mathrm{~ns}$ & 42.56 & $<0.001$ & 15.24 & $<0.001$ & 8.30 & 0.004 \\
$\mathrm{Ca}$ & 120.65 & 8.79 & $<0.003$ & 7.77 & $<0.006$ & 63.29 & $<0.001$ & 231.47 & $<0.001$ \\
$\mathrm{Mg}$ & 79.03 & 1.95 & $\mathrm{~ns}$ & 6.03 & $<0.015$ & 1.58 & $\mathrm{~ns}$ & 119.40 & $<0.001$ \\
$\mathrm{Na}$ & 44.82 & 0.38 & $\mathrm{~ns}$ & 0.97 & $\mathrm{~ns}$ & 368.49 & $<0.001$ & 3.19 & $\mathrm{~ns}$ \\
$\mathrm{~K}$ & 18.73 & 75.89 & $<0.001$ & 16.92 & $<0.001$ & 49.20 & $<0.001$ & 50.08 & $<0.001$ \\
$\mathrm{~N}$ & 242.35 & 50.37 & $<0.001$ & 0.73 & $\mathrm{~ns}$ & 936.93 & $<0.001$ & 741.35 & $<0.001$ \\
gash/gdm & 38.05 & 0.24 & $\mathrm{~ns}$ & 23.55 & $<0.001$ & & & 12.34 & 0.001 \\
gash/gafd & 28.08 & 0.11 & $\mathrm{~ns}$ & 13.84 & $<0.001$ & & & 13.78 & $<0.001$ \\
\hline
\end{tabular}




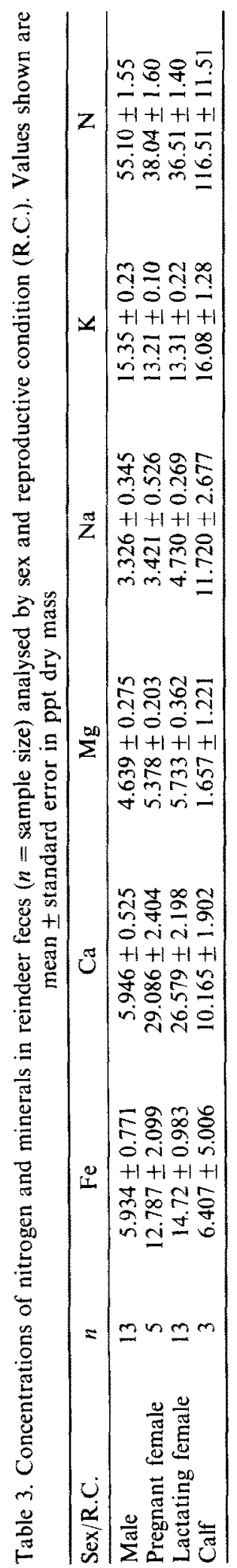

collected from males were statistically different than those collected from lactating and pregnant females in respect to all minerals except sodium. Dung produced by females was significantly higher in ash content than males (Table 4). Some plant and dung samples contained in acid insoluble ash upon digestion which may be related to iron levels within the samples (Table 5). The composition of dung produced by calves (Table 6) appears to change with increasing age of the calf.

\section{Discussion}

Statistically significant differences were found by sex in the mineral content of fecal samples collected in Iceland. Many factors could contribute to these differences, including variable nutritional requirements for males and females, reproductive conditions and locations, with respect to available food and soil type. Inherent differences between males and females could only be partially tested as all females analysed were either pregnant or lactating. Effects of antler growth could only be analysed for males as reproductively active females retain their antlers until mid-lactation.

The only foodstuff observed to be consumed by males along the E. Fjords was the grass species; however, this species may not be the main foodstuff of males. Females in Vesturoracfi appeared to consume all other species listed in Table 1, except Larix, Populus and the grass. Antlers are used as possible mineral supplements by both males and females. Barks collected in Hallormsstadur are not routinely eaten by reindeer, but were collected in response to previous problems with reindeer grazing on the bark of young saplings during the winter of 1991. Mineral analysis of foodstuffs in Hallormsstadur showed calcium and nitrogen content of barks to be greater than other available foodstuffs, providing the possibility that barks are eaten as nitrogen and calcium sources (Table 2). Other foodstuffs collected south of Hallormsstadur include Umbilicaria and Empetrum. The latter species, however, were also found through Vesturoraefi and are assumed to be eaten by reindeer in that region.

The following mineral analysis is based upon the assumption that high levels of 
Table 4. One-way ANOVA results $F$ and $P$ on nutrient element level content per gram dry mass (gdm) and per gram ash-free dry mass (gafd) in reindeer fecal samples (d.f. 1 and 28 in each case). A priori orthogonal contrast results (d.f. 2 and 28 in each case): F1 and $\mathrm{Pl}=\mathrm{Ho}$ : male generated dung $=$ female generated dung; F2 and $\mathbf{P 2}=\mathrm{Ho}$ : pregnant female generated dung $=$ lactating female generated dung. Those values which are not significant $(P>0.05)$ are listed as ns

\begin{tabular}{lrrrccc}
\hline Element & \multicolumn{1}{c}{$\mathrm{F}$} & \multicolumn{1}{c}{$\mathrm{P}$} & \multicolumn{1}{c}{$\mathrm{F} 1$} & $\mathrm{P} 1$ & $\mathrm{~F} 2$ & $\mathrm{P} 2$ \\
\hline $\mathrm{Fe}$ & 19.75 & $<0.001$ & 31.34 & $<0.001$ & 1.01 & $\mathrm{~ns}$ \\
$\mathrm{Ca}$ & 11.95 & $<0.001$ & 91.10 & $<0.001$ & 0.63 & $\mathrm{~ns}$ \\
$\mathrm{Mg}$ & 3.09 & 0.061 & 4.47 & 0.043 & 0.36 & $\mathrm{~ns}$ \\
$\mathrm{Na}$ & 5.12 & 0.013 & 2.74 & $\mathrm{~ns}$ & 4.41 & 0.045 \\
$\mathrm{~K}$ & 25.97 & $<0.001$ & 48.00 & $<0.001$ & 0.05 & $\mathrm{~ns}$ \\
$\mathrm{~N}$ & 43.92 & $<0.001$ & 76.40 & $<0.001$ & 0.30 & ns \\
gash/gdm & 24.85 & $<0.001$ & 47.02 & $<0.001$ & 0.29 & ns \\
gash/gafd & 16.31 & $<0.001$ & 30.57 & $<0.001$ & 0.11 & ns \\
\hline
\end{tabular}

minerals and nitrogen in the dung of reindeer relative to the respective recommended daily intake levels of nutrients for sheep indicate that reindeer are able to meet daily mineral requirements. Mineral and nitrogen concentrations are compared with minimal daily nutrient requirements for sheep as these data are readily available, and both animals are of similar mass. Although this study begins to give an indication of the nutrient status of reindeer in Iceland, conclusions made regarding mineral deficiencies are limited. Many factors affect absorption of minerals and nitrogen such as metabolic inhibitors and enhancers in foodstuffs; therefore, such analysis may overestimate or underestimate intake of particular minerals respectively. For some minerals, specific factors influencing $a b$ sorption efficiency are discussed below.

\section{Iron}

Foodstuffs collected in Vesturoraefi contained more iron than the grass collected along the eastern Fjords (Table 2). All species analysed, however, contained more than the $0.03-0.05 \mathrm{ppt}$ iron recommended daily for $90 \mathrm{~kg}$ ewes for maintenance (National Research Council, 1985). Dust storms are common in northeast Iceland,

Table 5. Number of digested foodstuff (specific tissue analysed is listed) and dung samples listed by reproductive condition of reindeer (R.C.) which contain any acid-insoluble ash (residue). Mean iron levels in $\mathrm{ppt}$ and total ash levels in $\mathrm{g} / 100 \mathrm{~g}$ are also reported. Total ash was determined by ashing remaining sample after ether extraction. Acid-insoluble ash is specified as a portion of total ash content that was not soluble after digestion (Studier and Sevick, 1992)

\begin{tabular}{llrcrc}
\hline Species/sex & Tissue/R.C. & $n$ & Residue & Fe & Ash \\
\hline Larix & Bark & 10 & 0 & 0.257 & 0.019 \\
Populus & Bark & 9 & 1 & 0.061 & 0.027 \\
Umbilicaria & Thallus & 20 & 20 & 4.475 & 0.103 \\
Empetrum & Above ground & 22 & 7 & 1.698 & 0.062 \\
Centraria & Entire lichen & 15 & 1 & 2.633 & 0.149 \\
Carex & Entire plant & 20 & 3 & 2.965 & 0.198 \\
Mixed lichen & Entire lichen & 20 & 2 & 1.240 & 0.064 \\
Salix & Above ground & 17 & 0 & 0.554 & 0.029 \\
Eriophorum & Above ground & 20 & 20 & 1.733 & 0.077 \\
Grass & Entire plant & 10 & 10 & 0.409 & 0.055 \\
Dryas & Above ground & 12 & 9 & 4.544 & 0.405 \\
Female dung & Pregnant & 5 & 5 & 12.787 & 0.505 \\
Female dung & Lactating & 13 & 13 & 14.724 & 0.479 \\
Male dung & & 13 & 13 & 5.934 & 0.177 \\
Calf dung & & 3 & 1 & 6.407 & 1.242 \\
Goose dung & & 1 & 1 & 24.711 & 4.476 \\
\hline
\end{tabular}


Table 6. Individual mineral and nitrogen levels (ppt dry mass) found in the dung of three Icelandic reindeer calves of specific age (in days) compared to mineral and nitrogen levels found in the milk of reindeer (Watt and Merril, 1975), with the exception of magnesium (ppt, $\mathrm{mg} / \mathrm{g}$ dry milk). Magnesium concentration is given for ewe's milk (National Research Council 1985)

\begin{tabular}{lrrrrrr}
\hline Age of calf & \multicolumn{1}{c}{$\mathrm{Fe}$} & $\mathrm{Ca}$ & $\mathrm{Mg}$ & $\mathrm{Na}$ & $\mathrm{K}$ & $\mathrm{N}$ \\
\hline $1-2$ & 0.102 & 5.510 & 0.093 & 16.940 & 13.25 & 135.20 \\
$2-3$ & 0.451 & 12.350 & 0.232 & 12.560 & 16.35 & 125.60 \\
$3-5$ & 18.668 & 12.640 & 4.646 & 5.670 & 18.66 & 88.95 \\
Milk & 0.003 & 7.070 & 0.160 & 4.370 & 4.42 & 172.80 \\
\hline
\end{tabular}

and volcanic glass, tephra and allophane clay materials, rich in $\mathrm{Fe}, \mathrm{Al}$ and $\mathrm{Mn}$ are likely to adhere to some foodstuffs consumed by reindeer (Olafur Arnalds, personal communication, 1993). These dust storms are not as prevalent along the eastern fjords, possibly contributing to less sedimentation, and lower iron concentration found on the grass species. Lower iron levels in soil may directly influence inherent mineral content of grass.

Lower iron concentrations found in dung generated by males along the eastern fjords compared to dung generated by females in Vesturoraefi support such a hypothesis (Table 5). Lactating females most likely have an increase in minimal dietary iron need. Ewe's milk only contains $0.003 \mathrm{ppt}$ of iron (National Research Council, 1985), and reindeer milk is not assumed to vary greatly in composition from this. Such small increases in dietary iron requirement alone are unlikely to account for the additional $7 \mathrm{ppt}$ of iron found in the dung of lactating females compared to the dung of males, indicating that iron is more prevalent in plants eaten in Vesturoraefi. High levels of iron in dung of males, and especially of females, may be a result of protective functions of mucosal cells of the gut to avoid iron toxicity. Mucosal cells lining the intestine of rats have been shown to regulate iron absorption in response to changes in mucosal cell iron concentration (Adams et al., 1991). Iron has been found to be toxic to sheep at ingested levels greater than $0.5 \mathrm{ppt}$ (National Research Council, 1985), and, may pose a threat to reindeer if nearly $0.5 \mathrm{ppt}$ of iron is assimilated. Alternatively, an unavailable form of iron may be prevalent in these foodstuffs contributing to high iron levels found in feces.
Iron-rich plants are not unique to Iceland. High iron concentrations are also found in Svalbard vegetation, but not in Norway (0.266 ppt) (Staaland et al., 1983). Mean iron levels found in winter and summer pastures (dry mass) of Adventdalen, Svalbard were (mean $\pm \mathrm{SE}$ ) $7.899 \pm 4.053 \mathrm{ppt}$ and $3.671 \pm 2.313 \mathrm{ppt}$ respectively (Staaland et al., 1983). Feces (dry mass) collected from the distal colon of reindeer consuming such foodstuffs were found to contain $15.695 \mathrm{ppt}$ and $4.392 \mathrm{ppt}$ iron in winter and summer, respectively. Although iron concentrations are slightly higher in foodstuffs collected in Svalbard, the amount found in feces is similar to values found in Iceland. Borch-Iohnsen and Nilssen (1987) described a seasonal iron overload which occurs in parenchymal and nonparenchymal liver cells of Svalbard reindeer. Such overload is associated with increased iron absorption as a result of high dietary intake and break-down of lean tissue of reindeer during harsh winters. Up to $47 \%$ of summer body mass is lost during winter months in Svalbard reindeer (Reimers et al., 1982). Studies of adult females in Iceland during 1979-1980 show a $25 \%$ decrease in mean carcass weight from August/September through to May (Thorisson, 1984). Dietary iron intake is high in Iceland, and an iron overload could occur during harsh winters when losses of lean body tissue are above average.

Borch-Iohnsen and Nilssen (1987) also found rumen iron concentrations higher in Svalbard reindeer living more inland than those on the coast. The Svalbard pattern is similar to that found in Iceland. Rumen contents of males and females found in the same areas showed no differences (BorchIohnsen and Nilssen, 1987); therefore, higher fecal iron concentrations found in 
Icelandic male reindeer than female reindeer are mainly attributed to location differences and not inherent differences of gender or reproductive condition.

\section{Calcium}

Dietary minimal calcium recommended levels for female sheep are 2.07, 3.20 and $3.56 \mathrm{ppt}$ dry mass for maintenance, pregnancy and lactation, respectively (National Research Council, 1985). The grass species eaten by male reindeer offers statistically less calcium than other non-bark foodstuffs available to female reindeer (Table 2). Such low calcium intake may be inadequate for males during antler (168 ppt) development; however, other foods not analysed may provide enough calcium to meet minimal daily requirements. Of those foods available to female reindeer at Vesturoraefi, Cetraria, mixed lichen and Dryas are the best calcium sources. If reindeer requirements are similar to sheep, all foodstuffs analysed in the area, except Umbilicaria, would allow reproductively active females to meet dietary calcium requirements.

Egilsson (1983) indicated that lichens, particularly all Cetraria spp., have been overgrazed in Vesturoraefi. Norwcgian and Svalbard reindeer are mixed feeders and select the most nutritious and digestible portions of plants to consume (Hoffman, 1973). Icelandic reindeer appear to select nutritionally valuable foods as cvidenced by overgrazing of Cetraria nivalis. In May 1992, few lichens, especially Cetraria nivalis, were found throughout the calving area. These lichens, therefore, can only serve as dietary supplements in this area and cannot make up a large percentage of the reindeer diet. Lichens are only $0.16 \%$ of the reindeer diet during the summer months (Egilsson, 1983). In areas, such as Jokuldalsheidi, lichens comprise $41 \%$ of the spring diet of reindeer (Egilsson, 1983). High calcium concentrations in mixed lichen and Cetraria nitalis, as well as, high magnesium and sodium concentrations found in Cetraria nivalis, may be the cause of overgrazing of lichens by reindeer. Increased calcium requirements during pregnancy, lactation and antler growth during the summer may cause increased selection of Cetraria. White et al. (1984), however, do not support this hypothesis as they suggest lichens may complex with calcium, rendering it unavailable for assimilation by reindeer, i.e. high concentrations of calcium found in lichens may be misleading. They were studying non-reproductively active reindeer, however, and calcium absorption has been shown to increase with increased requirement and intake (White et al., 1984). Perhaps additional stresses of pregnancy, lactation and antler growth could increase calcium absorption from lichens.

Care et al. (1979) have summarized the physiological manifestations of increased calcium requirements in ruminants. Female reindeer in Iceland appear to be meeting calcium requirements as fecal calcium concentrations are much greater than reported daily recommended levels for sheep. Even if lichens complex calcium, Dryas is widely available as a calcium rich source in Vesturoraefi (Table 1). Bone resorption is probably occurring in females as plasma calcium concentrations drop and may mask a calcium intake deficiency (Care et al., 1979). One fecal sample, collected from a lactating female, within $3 \mathrm{hr}$ of parturition in Skriddalur, contained calcium, magnesium, sodium and iron levels which were much lower than all others collected from lactating cows in Iceland. These characteristics are consistent with symptoms of parturient paresis as described by Care et al. (1979).

Not surprisingly, malc reindecr appear to exhibit calcium stress during May when they are developing antlers. Pregnant and newly lactating females do not require excess calcium for antler development since reproductively active females retain their antlers until shortly after parturition. Fecal calcium concentrations are significantly lower in males than pregnant and lactating females (Table 4) and are much less variable in male generated dung than female generated dung. Also, when mineral concentrations were statistically analysed among males in different locations along the eastern fjords, all minerals were significantly different in concentration in dung with the exception of calcium (Table 4). All these data suggest males are using all possible mechanisms to absorb as much calcium as possible from ingested foodstuffs and are most likely sequestering that calcium in the antlers. Because grass supplies little calcium 
in relation to calcium demand during this time (Table 1), males may be forced to supplement grass to obtain required calcium. Reindeer were commonly seen chewing shed antlers in Vesturoraefi. Males along the eastern fjords would benefit from consuming such calcium rich material for antler development (Table 3).

\section{Magnesium}

Daily dietary magnesium recommended levels for maintenance in sheep are 1.2-1.8 ppt dry mass (National Research Council, 1985). All plants analysed, with the exception of Umbilicaria and mixed lichen, have magnesium concentrations within or above this range (Table 1). Although the magnesium composition of reindeer milk has not been established, $0.016 \mathrm{ppt}$ is found in sheep's milk (National Research Council, 1985). Little increased requirement, therefore, is expected for lactating females. Males and females produced dung statistically different in magnesium content (Table 4). Differences may be a result of varying levels of magnesium intake or protein, sodium and potassium intake as described below.

Martens and Rayssiguiers (1979) have found four factors which lead to hypomagnesaemia in ruminants. Hypomagnesaemia has been shown to develop in ruminants when their diet contains $0.20 \%$ (dry mass) magnesium, when protein and sodium intake is high, and when energy intake is low. Grass contains statistically more nitrogen and sodium than all foodstuffs tested (Table 2). Although grass is not the male reindeer's only source of magnesium, other foods consumed at that site may also be high in sodium as a result of close proximity to the ocean, and new plant growth is generally high in nitrogen content. These characteristics may lead to high magnesium concentrations found in the dung of male reindeer during spring. Although sodium concentration of grass most likely remains relatively stable throughout the year, protein concentration will decrease with age of growth. Hypomagnesaemia may only be a problem for reindeer during spring months when vegetation is collectively high in protein content.

\section{Sodium}

Fecal sodium concentrations were not significantly different in dung of males and females (Table 4), even though grass analysed from the eastern fjords contained statistically higher sodium levels than nonbark foodstuffs consumed by females (Table 2). Very few food species, however, contained sodium concentrations equal to the dietary recommended levels for sheep which are 0.9-1.8 ppt (National Research Council, 1985). In fact, all foodstuffs analysed from Vesturoraefi, contain insufficient sodium for reindeer to meet maintenance requirements. Pregnant and lactating reindeer have increased sodium requirements, most notably lactating females for milk production (4.3 ppt in dry milk) (Watt and Merril, 1975). Since lichens are scarce on Vesturoraefi, main sodium sources are Carex and Dryas, which apparently do not contain enough sodium for maintenance requirements. Selection of sodium rich foods by females, which we did not collect or analyse, may also explain high levels of sodium found in dung. Statistically higher levels of sodium are found in the dung of lactating females than in pregnant females (Table 4). Since lactating females probably have greater sodium requirements for milk production, selection of sodium rich foods or greater mobilization of endogenous sodium pools may explain higher levels of sodium in the dung of lactating females than pregnant females. Shed antlers could also provide reindeer with excellent calcium, magnesium and sodium supplements during times of increased mineral requirements.

High sodium and potassium levels in grass (Table 1), which was consumed by males grazing along the eastern fjords, are associated with close proximity to the ocean. Sea spray has been shown to increase mineral concentration of plants (Lag, 1968); therefore, many plants along the eastern fjords may have increased sodium and potassium composition. Dung, on the other hand, was not likely to be affected by sea spray as dung was immediately collected. This hypothesis is supported by higher sodium levels in the dung of males in Hamarsfjordur (4.05 ppt dry mass) than in Flatey (2.28 ppt dry mass) and Lake 
Thveit (1.88 ppt dry mass) (Table 4 ). The latter two areas are much further inland, and the influence of sea spray on mineral composition of nearby foodstuffs would not be as prevalent in those inland areas. Although males do have an increased dietary sodium requirement for antler growth, grass should supply adequate sodium.

\section{Potassium}

All foodstuffs analysed in Vesturoraefi contain enough potassium for reindeer to meet dietary requirements of sheep which is 5.0-8.0 ppt (National Research Council, 1985). Milk contains $4.37 \mathrm{ppt}$ of potassium (dry) and milk production would result in increased potassium need by lactating females. Although potassium intake requirements certainly increase for pregnant reindeer, quantitative data are not available. Endogenous potassium stores are not as great for other minerals previously described, but dietary intake should be able to supply additional potassium necessary for reproductively active females. Most potassium found in dung of females is, therefore, probably dietary in origin. Potassium concentrations in dung produced by males wcre greater than those found for females. High potassium content in grass versus other non-bark plant materials allows males to ingest more of this mineral (Table 2).

\section{Nitrogen}

Nitrogen is an extremely important nutrient for reindeer and other ruminants. Low concentrations of nitrogen in foodstuffs decrease fermentation by decreasing activity of microflora present in the rumen, therefore, decreasing cellulolysis and digestibility of ingested foodstuffs. Much of the nitrogen excreted in dung is associated with microbes originating from the rumen (Staaland and White, 1991). Grass is an excellent nitrogen source for males along the eastern fjords. Extremely high levels of nitrogen in this grass (Table 1), which is consumed during spring, account for the high levels of nitrogen in the dung of males. Most males had begun to develop antlers, however, suggesting dietary nitrogen intake was more than sufficient for maintenance. Nitrogen digestibility has been shown to increase with increased level of mineral intake in reindeer consuming a manufactured diet (White et al., 1984). Grass has high concentrations of sodium, potassium, and to some extent, magnesium (Table 1). Such inherently high dietary concentrations of minerals, therefore, may increase nitrogen digestibility by male reindeer.

Lactating and pregnant females have incrcased nitrogen demands for both milk production and fetal development. Compared to non-reproductively active females, female sheep, in late gestation, have nearly twice the protein recommended level and, in carly lactation, have three times higher than the recommended level (National Research Council, 1985). Compared to males, females have access to foodstuffs which are lower in nitrogen content, but still contain nitrogen levels greater than dietary requirements. Egilsson (1983) reported that in areas of Iceland inhabited by reindeer, Salix was in danger of being over grazed. Selection of Salix by female reindeer may be directly related to high nitrogen levels found in that species. Females, therefore, appear to meet their dietary nitrogen requirements.

\section{Mineral supplements}

Reindeer on the Svalbard Islands have been shown to have negative nitrogen, sodium and potassium balances in early spring due to depletion of stores of nitrogen and these minerals whilc cating poorly mineralized foodstuffs during winter (Staaland et al., 1988). This imbalance, leading to salt hunger in spring explains observations of reindeer chewing dropped antlers, visiting salt licks, eating soil and urine contaminated snow, and drinking sea water (Staaland et al., 1980). Shed antlers, which are found throughout Vesturoraefi and the eastern fjords, may serve as supplements to reindeer in negative mineral and nitrogen balance, as Icelandic reindeer were occasionally found chewing antlers, suggesting their importance in maintaining mineral balance.

Thorisson hypothesized that reindeer consume feces from Pink-Footed Geese. Goose dung is plentiful on Vesturoraefi and fragments of plant material appear to make up most of the dung. An important constituent of pink-footed goose diet in spring are roots of Polygonum viviparum. Analysis 
of a single sample of goose guano showed that mineral content is extremely high (24.71 ppt Fe, 23.03 ppt Ca, 7.10 ppt Mg, $7.25 \mathrm{ppt} \mathrm{Na}, 15.02 \mathrm{ppt} \mathrm{K}, 31.95 \mathrm{ppt} \mathrm{N}$ ). Calcium and magnesium content is twice as high as the best plant sources, and sodium content is slightly greater than the grass found along the eastern fjords. Iron is extremely concentrated, however, and may be toxic to reindeer if assimilated. Thorisson's hypothesis, in any case, certainly warrants testing a much larger sample of goose dung.

\section{Ash and acid-insoluble ash}

Completc oxidation of most materials digested has been achieved by the methods of Studier et al. (1992) with the exception of a few plastics in waste from a sewage treatment plant. Many soil samples and all dung samples, with the exception of dung produced by two young calves, however, contained an indigestible, solid black residue after treatment with sulfuric and persulfuric acid (Table 5). This acidinsoluble ash is associated with soil particles which adhere to foodstuffs consumed by reindeer. As mentioned previously, plants in northeast Iceland are exposed to dust storms and occasionally volcanic explosions which cover these plants with tephra, rich in Fe, $\mathrm{Al}$ and $\mathrm{Mn}$. The $\mathrm{Mn}$ in these samples has been shown to disrupt oxidation processes which use peroxide (Arnalds, personal communication, 1993) explaining why the presence of acid insoluble ash appears to accompany high levels of iron in foodstuffs. The presence of acid insoluble ash did not seem to depend on total ash content.

Significantly higher levels of total ash were eliminated in dung by females than males. This difference is attributed to more ash found in foodstuffs consumed by females on Vesturoraefi than the grass consumed by males along the eastern fjords.

\section{Nutritional status of calves}

Dung samples were collected from three very young calves in Vesturoraefi. Although the sample size is small, differences in all element compositions are striking as the calves increase in age. Table 6 shows increases in iron, calcium, magnesium and potassium concentrations and decreases in sodium and nitrogen concentrations of dung with age of the three calves studied. These trends can be described by two simultaneously occurring phenomena. Although lacking in dung samples from younger calves, the dung sample from the oldest calf (3-5 days) contained the acid insoluble ash which was present in all adult samples. Because many plant species also contain such a residue after digestion, the oldest calf tested had apparently begun, along with milk, to consume plants and adherent soil, which was not oxidized completely by laboratory digestion. This possibility is supported by high levels of iron found in the feces of the calf that was 3-5 days old (Table 6). In all cases where mineral concentration in dung increases with age, minerals are found in greater concentrations in foodstuffs than milk causing mineral elimination to be greater.

Secondly, as calves age, nitrogen concentration in dung decreases as a result of decreased protein intake and as a probable result of increased nitrogen taken up by microbes becoming established. Reindeer milk is rich in nitrogen (172.8 ppt) in comparison with available plant materials. Ingestion of some plant material in addition to milk, therefore, would decrease dietary nitrogen density. Ruminants are born with a nonfunctional rumen, and dietary protein is necessary to provide a source of nitrogen for microbes in the rumen so that it becomes functional (National Research Council, 1985). Perhaps our analysis of calf dung indicates that the rumen is slowly becoming more functional, and assimilation efficiencies are increasing. Based on the amount of acid insoluble and soluble ash in dung, calf three does not appear to have a fully functional rumen. Acid soluble ash content is much higher than in all other fecal samples collected as a result of the calf's inability to break down plant material. Within 3-5 days, only a limited population of microflora would be developed in the rumen.

Acknowledgements-We thank Dr P. Hersteinsson for his help in making arrangements for samplc collection in Iceland, and Dr K. Lavoie and Dennis Viele, for useful comments on this manuscript. We are indebted to Halldor Stcfansson and Thor Thorfinnsson for aid in sample collection. 
We thank Dr Leo Bruederle for classifying the grass species found along the eastern fjords. Dr Olafur Arnalds provided helpful comments in regard to Iceland's soil types, and Dr Hans Staaland was gracious in sending many useful articles pertaining to reindeer nutrition. We are indebted to Dr Russell Schenck for his help with statistical analysis. Heather McNamara, Beth McGraw and Brenda Sandy Flores also helped in sample processing. This project was supported in part by the Honor's Department at the University of Michigan-Flint.

\section{References}

Adams P. C., Zhong R., Houst J., Flannagan P. R. and Grant D. R. (1991) Mucosal iron in the control of iron absorption in a rat intestinal transplant model. Gastroenterology 100, 370-374.

Borch-Iohnsen B. and Nilssen K. J. (1987) Seasonal iron overload in Svalbard reindeer liver. American Institute of Nutrition 22, 2072-2078.

Care A. D., Barlet J. P. and Abdel-Hafeez H. M. (1979) Calcium and phosphate homoeostasis in ruminants and its relationship to the aetiology and prevention of parturient paresis. Digestive Physiology and Metabolism in Ruminants. Proceedings of the 5th International Symposium on Ruminant Physiology (Edited by Y. Ruckebusch and P. Thivend.), pp. 429-445. MTP Press Limited, Lancaster.

Chase L. C. (1993) Nutritional Status of Reindeer in Iceland. University of Michigan-Flint Library. Honors Thesis.

Egilsson K. (1983) The food and pastures of reindeer in Iceland. Icelandic Energy Authority, p. 235. Orkustonun 05-83073/VOD-07.

Hoffman R. R. (1973) The ruminant stomach. East African Monographs in Biology, Vol. 2. East African Literature Bureau. Nairobi.

Lag J. (1968) Relationships between the chemical composition of the precipitation and the content of exchangeable ions in the humus layer of natural soils. Acta Agric. Scand. 18, 148-152.

McEwan E. H. and Whitehead P. E. (1970) Seasonal changes in the energy and nitrogen intake in reindeer and caribou. Canadian. J. Zool. 48, 905-913.

Martens H. and Rayssiguies Y. (1979) Magnesium metabolism and hypogmagnesaemia. Digestive Physiology and Metabolism in Ruminants. Proceedings of the Sth International Symposium on Ruminant Physiology (Edited by Ruckebusch Y. and
Thivend P.), pp. 447-465. MTT Press Limited, Lancaster.

National Research Council (1985) Nutrient Requirements of Sheep, 6th ed. National Academy Press, Washington, D. C., 99 pp.

Reimers E., Ringberg T. and Sorumgard R. (1982) Body composition of Svalbard reindeer. Canadian J. Zool. 60, 1812-1821.

Staaland H., Brattbakk I., Ekern K. and Kildemo K. (1983) Chemical composition of reindeer forage plants in Svalbard and Norway. Holarctic Ecol. 6, 109-122.

Staaland H., Hove K. and White R. G. (1986) Mineral absorption in relation to nutritional ecology of reindeer. Rangifer 1, 279-287.

Staaland H., Ortsland N. A. and White R. G. (1988) Digestion of energy and nutrients in Svalbard reindeer. Rangifer $\mathbf{8}, 2-10$.

Staaland H. and White R. G. (1991) Influence of foraging ecology on alimentary tract size and function of Svalbard reindeer. Canadian J. Zool. 69, 1326-1334.

Staaland H., White R. G., Luick J. R. and Holleman D. F. (1980) Dietary influences of sodium and potassium metabolism of reindeer. Canadian $J$. Zool. 58, 1728-1734.

Studier E. H. and Sevick S. H. (1992) Live mass, water content, and nitrogen and mineral levels in some insects from south-central lower Michigan. Comp. Biochem. Physiol. 103A, 579-596.

Thorisson S. (1980) Status of Rangifer in Iceland. In Proc. 2nd Int. Keindeer/Caribou Symp., Roros, Norway, 1979 (Edited by Reimers E., Gaare E. and Skjenneberg S.), pp. 768-770. Direktoratet for vilt og ferksvannsfisk, Trondheim.

Thorisson S. (1984) The history of reindeer in Iceland and reindeer study 1979-1981. Rangifer 4, 22-38.

Treybig D. S. and Haney P. L. (1983) Colorimetric determination of total nitrogen in amines with selenium catalyst. Analyt. Chem. 55, 938-985.

Watt B. and Merrill A. (1975) Composition of Foods. Agricultural Handbook No. 8, p. 96. U.S. Department of Agriculture, U.S. Govt. Printing Office: Washington, D.C.

White R. G., Jacobsen E. and Staaland H. (1984) Secretion and absorption of nutrients in the alimentary tract of reindeer fed lichens or concentrates during the winter. Canadian J. Zool. 62, 2364-2376.

Wilkison L. (1989) SYSTAT: The System for Statistics. SYSTAT, Inc., Evanston, IL, 822 pp. 